\title{
VARIED METHODS OF PROTECTION OF TRAVELLERS UNDER EUROPEAN LAW
}

\section{DOROTA AMBROŻUK}

University of Szczecin, Faculty of Management and Economics of Services, POLAND

e-mail: dorota.ambrozuk@wzieu.pl

\begin{tabular}{l|l}
$\begin{array}{l}\text { RECEIVED } \\
\text { JEL }\end{array}$ & $\begin{array}{l}18 \text { January } 2018 \\
\text { 2 September } 2018\end{array}$ \\
KEASSIFICATION & K12, K22 \\
ABSTRACT & $\begin{array}{l}\text { A harmonisation of legal regulations with respect to traveller (passenger) protection in the context of travel and } \\
\text { carriage services has taken place recently in the European Union. This is the consequence of the entry into force } \\
\text { of Directive (EU) 2015/2302 of the European Parliament and of the Council of 25 November } 2015 \text { on package } \\
\text { travel and linked package arrangements, which also classifies the service of the carriage of passengers as } \\
\text { a travel service. In the case of both type of services, the European Union legislator aimed to provide travellers } \\
\text { with a high, reasonably uniform, level of protection. However, he used to this end different legal instruments } \\
\text { and protection methods. This paper attempts to compare the instruments and methods of traveller protection } \\
\text { applied by the European Union legislator in EU law through showing their advantages and disadvantages. }\end{array}$
\end{tabular}

\section{Introduction}

The entry into force of Directive (EU) 2015/2302 of the European Parliament and of the Council of 25 November 2015 on package travel and linked travel arrangements, amending Regulation (EC) No. 2006/2004 and Directive 2011/83/EU of the European Parliament and of the Council and repealing Council Directive 90/314/EEC (OJ UE $2015 \mathrm{~L} \mathrm{326/1)}$ resulted in the concept of a traveller, which had been applied so far to the regulation within the scope 
of the carriage of persons, being related to persons using the services of tour operators, inclusive of travel agents. This is an example of the approximation of legal regulations to some extent with respect to transport services and travel services. The Package Travel Directive expressly states that carriage of passengers is a travel service (article 3(1)(a) of directive 2015/2302). Furthermore, this new regulation contains references to European Union regulations which govern contracts for the carriage of passengers in particular modes of transport ${ }^{1}$.

The aim of the new directive is to adjust the level of traveller protection to a changing market of travel services. It is emphasized in legal writing that the regulations contained in the new Package Travel Directive should foster transparency and legal certainty. This is because not only does package travel consist of particular services created earlier and offered to travellers in the form of a package, but also packages created or customized to meet individual clients' needs (the so called dynamic package), often bought on-line, have become encompassed by legal framework (Gospodarek, 2014, p. 166). At the same time, European Union legislator - as results from Article 1 of the directive - wanted to achieve a high and uniform as much as possible level of consumer protection. Noticeably, it is not only consumers who use travel or carriage services (Karsten, 2007, pp. 126-131).

Regulations of particular modes of transport have a similar objective. Carriage of passengers, similarly to travel services, have been on the European Union legislator's agenda for a long time as part of common EU transport and consumer policy. Also in this case the European Union legislator saw the need to unify the provisions and strengthen the protection of passengers as the weaker party to contracts of carriage, considering the present regulations included in international conventions ${ }^{2}$ and internal regulations of the particular member States to be insufficient (Ambrożuk, 2014, pp. 11-24).

The aim of this paper is to compare methods of protection of travellers applied by the European Union legislator in EU law and to show their advantages and disadvantages. Due to the length of this paper, the comments

\footnotetext{
1 That is, the following regulations: Regulation (EC) No. 261/2004 of the European Parliament and of the Council of 11 February 2004 establishing common rules on compensation and assistance to passengers in the event of denied boarding and of cancellation or long delay of flights, and repealing Regulation (EEC) No. 295/91 (OJ UE 2004 L 46/1); Regulation (EC) No. $1107 / 2006$ of the European Parliament and of the Council of 5 July 2006 concerning the rights of disabled persons and persons with reduced mobility when travelling by air (OJ UE 2006 L 204/1); Regulation (EC) No. 1371/2007 of the European Parliament and of the Council of 23 October 2007 on rail passengers' rights and obligations (OJ UE 2007 L 315/14); Regulation (EC) No. 392/2009 of the European Parliament and of the Council of 23 April 2009 on the liability of carriers of passengers by sea in the event of accidents (OJ UE 2009 L 131/24); Regulation (EC) No. $1177 / 2010$ of the European Parliament and of the Council of 24 November 2009 concerning the rights of passengers when travelling by sea and inland waterway and amending Regulation (EC) No 2006/2004 (OJ UE 2010 L 334/1); Regulation (EC) No. 181/2011 of the European Parliament and of the Council of 16 February 2011 concerning the rights of passengers in bus and coach transport and amending Regulation (EC) No. 2006/2004 (OJ UE 2011 L 55/1).

2 These are the following conventions ratified by Poland: Convention concerning International Carriage by Rail (COTIF) of 9 May (Dz.U. of 1985 No. 34, item 158), as amended by the Vilnius Protocol of 3 June 1999 (Dz.U. of 2007 No. 100, item 674), Appendix A. Uniform Rules concerning the Contract of International Carriage of Passengers by Rail (CIV); two air flight conventions: the so called Warsaw Convention, that is the Convention for the Unification of Certain Rules Relating to International Carriage by Air of 12.10 .1929 r. (Dz.U. of 1933 No. 8, item 49), amended by the Hague Protocol of 28.9.1955 (Dz.U. of 1963 No. 33, item 189), supplemented by the Convention for the Unification of Certain Rules Relating to International Carriage by Air Performed by an Entity other than the Carrier under the Contract of 18.9.1961 (Dz.U. of 1965 No. 25, item 167) and the so called. Montreal Convention that is the Convention for the Unification of Certain Rules for International Carriage by Air of 28.5.1999 (Dz.U. of 2007 No. 37, item 235); the Athens Convention relating to the Carriage of Passengers and their Luggage by Sea of 13.12.1974 (Dz.U. of 1987 No. 18, item 108) as amended by the Protocol to the Athens Convention of 19.11 .1976 (Dz.U. of 1994 No. 99, item 479). Poland has not ratified the Protocol of 2002 to the Athens Convention which came into force on 23.4.2014. The EU acceded to this Protocol by virtue of two decisions of the Council of 12.12.2011 (OJ UE L8/1 as amended and OJ UE L 8/13 as amended). Pursuant to Article 216(2) of the Treaty on the Functioning of the European Union (consolidated version - OJ EU 2012 C326/1) Poland is obliged to apply the Protocol of 2002 with respect to EU carriage.
} 
will pertain uniquely to civil law regulations connected with contracts made between travellers and carriers and tour operators. Traveller protection, in particular in the context of travel services, also has other aspects, inclusive of those connected with public law, which are beyond the scope of this paper.

\section{The differenences of methods applied}

In the case of transport services, the European Union legislator used the most far-reaching instrument of unification a regulation, which due to its direct application does not require implementation by the EU Member States. The European Union legislator maintained, however, the separate-in-nature character of regulation of the particular modes of transport and issued a number of regulations ${ }^{3}$. These regulations do not include, however, a comprehensive regulation of contracts for the carriage of passengers in particular modes of transport. The regulatory framework of international conventions regulating particular modes of international transport became the starting point for the European Union legislator. Thus the scope of their application has been extended also to domestic carriage within the territory of the EU. Noticeably, transport conventions in force contain, as a rule, mandatory provisions, which result from their wording (e.g. Article 49 of the Montreal Convention; Article 32 of the Warsaw Convention, Article 18 of Athens Convention. However in the case of CIV, its provisions are mainly semi-imperative, which results from Article 5 of this Convention). The regulations contain, however, provisions referring only to selected problems and generally of a semi-imperative nature. They refer both to issues regulated by international conventions, as well as issues which are beyond of the scope of these Conventions.

A regulative measure applied in the form of a regulation guarantees far-reaching unification of the situation of travellers in the UE. However, a lack of a comprehensive regulation of contracts of carriage for particular modes of transport causes a number of problems. The systems of traveller protection with a complex structure as created consists of EU legislation, international conventions and domestic law. EU regulations, similarly to international conventions, do not regulate all possible aspects, leaving a lot of issues to domestic law. Thus, a phenomenon which is described in legal writing as multicentricity of regulations occurs, with all its consequences (Wesołowski, 2016, pp. 201-215). These are reflected, among others, in uncertainty as to the applicable provisions and remedies available to passengers. Examples of such uncertainty can be found in case law of the Court of Justice of the European Union (e.g. the judgement of 22 November 2012; C-139/11 Moré, ECLI:EU:C:2012:741; the judgement of 22 October 2009; C-301/08 Bogiatzi, ECLI:EU:C:2009:649) or of national courts (e.g. a resolution of the Polish Supreme Court of 7 February 2014; III CZP 113/13, www.sn.pl/sistes/orzecznictwo/orzeczenia2/iii czp 113-13.pdf or a resolution of this Court of 17 March 2017 r., III CZP 111/16, www.sn.pl/sistes/orzecznictwo/orzeczenia3/iii czp 111-16.pdf, accessed on 6.06.2018). They refer, among others, to time-limits for bringing proceedings established based on different bodies of law (European Union, international or domestic) (see also, Ambrożuk, Wesołowski, awaiting publication) or authorities before which proceedings may be brought (see further, Ambrożuk, 2015, pp. 155-169; Ambrożuk, 2017, pp. 48-60).

European Union legislator chose a completely different route with respect to protection of travellers using services of tour operators. In international law there is no model regulation of protection for such travellers to which

\footnotetext{
${ }^{3}$ Apart from the regulations mentioned above, another important regulation is Regulation (EC) No. $2027 / 97$ of 9.10 .1997 on air carrier liability in respect of the carriage of passengers and their baggage by air (OJ UE $1997 \mathrm{~L}$ 285/1) as amended by (EC) No. $889 / 2002$ of the European Parliament and of the Council of 11.05.2002 (OJ UE 2002 L 140/2, Polish Special Edition 2004, chapter 7, vol. 6, p. 246).
} 
the European Union legislator could refer. Thus, under tourism law, the role of the European Union legislator was to develop a certain standard of protection for such travellers and to impose it upon the Member States. It refrained, however, from using a more far-reaching measure such as a regulation. It confined itself to adoption of directive no. 2015/2302 on the maximum level of harmonisation (Article 4), (see Marak, 2015, pp. 16-28). Member States, when adopting internal regulations, may not maintain or introduce into their domestic law provisions different from the ones adopted in the directive, inclusive of provisions which are more stringent for a tour operator, as this would lead to differences in the level of traveller protection. Thus, this standard for all Member States should, as a rule, be unified. Its purpose is to increase the transparency and certainty of law for both travellers and entrepreneurs.

The previous Package Travel Directive no. 90/314/EEC provided a minimum level of harmonisation. Thus, Member States could have guaranteed to clients of tour operators, by way of domestic law, a higher degree of protection than the one resulting from the directive (Nesterowicz, 2012, p. 20; Ambrożuk, Wesołowski, 2001, p. 75; Gospodarek, 2001, p. 26).

However, even a directive providing for the highest level of harmonisation may be improperly implemented. An example of this is the provisions of the Act of 24 November 2017 on package travel and linked travel arrangements (Dz.U. of 2017, item 2361), whereby the Polish legislator made no effort to adjust the terminology to concepts used in domestic law. Accordingly in the act, the Polish legislator adopts the term "performance" of the contract for package travel, whereas in the context of contracts, the term "fulfilment" of the obligation (the contract) is used in Polish civil law. Similarly, instead of using the term "failure to perform or improper performance of the contract", which is established in Polish civil law, the legislator applied automatically the term "non-compliance". Many more examples of this could be found. There are also cases where the Polish legislator implemented the provisions in such a way that the actual meaning of the provisions of the directive was changed. This is illustrated by the provisions of Article 50(3)(1\&2) of the aforementioned Polish act. Pursuant to these provisions, a traveller is not entitled to damages or compensation for noncompliance of travel services with the contract when the organiser of the tour can prove that the noncompliance is culpable to the traveller (first paragraph) or to a third party, unrelated to the performance of a travel service as covered by the contract for package travel, and the non-compliance could not have been foreseen or avoided (second paragraph). Directive no. 2015/2302, in its Article 14(3) (a\&b) does not require, however, that the cause on the part of the traveller or a third party is culpable.

Another example of incorrect implementation is the provision of Article 50(5) of the Polish act by virtue of which a tour operator may invoke with respect to the traveller the same restrictions which result from specific provisions connected with the liability of the provider of the travel service, which is part of package travel. However, the provision of Article 14(4) of directive no. 2015/2302 mentions international conventions and not specific provisions. The term "international conventions" is not the same as the term "specific provisions" as the latter ones may result from internal (domestic) regulations as enacted.

\section{The method of travellep protection}

As already mentioned, European Union regulations connected to carriage refer to both, issues regulated by the provisions of international conventions and contain as well, provisions connected with issues which have not been regulated so far on a transnational scale. In the first case, the European Union legislator improved the existing level of protection for travellers using carriage services (e.g. within the scope of limits of the amount of compensation due from the carrier for loss of life, health or luggage). In the second, passengers were granted additional rights, 
e.g. the right to an advance payment on compensation in the case of personal damage, rights for passengers who are disabled or with limited mobility, the right to the so called flat-rate compensation for passengers in the event of the cancellation of a run (a flight), delay in carriage, non-admission on board the means of transport and the right to make a complaint (Ambrożuk, 2014, p. 12). Thus, in the context of transport law, the protective function of the provisions of the European Union regulations consists of strengthening passengers' protection in relation to standards resulting from international conventions and granting new rights which were not present so far.

The situation is quite different in the case of travel services, where there are no equivalent convention regulations. There is no model regulation in international law with respect to protection of travellers using the services of tour operators, to which the European Union legislator could refer. Traveller protection in international law consists most of all of the introduction of certain limitations as to the contractual relationships between a tour operator and a traveller so it is not too burdensome for the traveller. Thus, generally the point is not to grant a traveller new rights compared to general provisions on contractual liability but to stop tour operators from imposing on travellers conditions which are difficult to accept from an axiological perspective using the fact that these provisions are ius dispositivum. Such an approach results from monitoring the travel service market and tour operators' abuse of the principle of freedom of contract as determined. Accordingly, it would seem that the method of protection as applied is in line with the postulate of consumer law, that is the restoration of balance between the entrepreneur and the consumer, disturbed by entrepreneur's dominant economic, organizational and legal position (Łętowska, 2006, p. 42). However, it is difficult to miss that the method of regulation applied strengthens certain deviation from standards resulting from general rules connected with contractual liability to the detriment of a traveller. A similar level, and in some aspects even higher, of protection of travellers could be achieved by applying to the package travel contract general rules on performance or the consequences of non-performance or improper performance of contracts contained in the civil codes of the particular states. These provisions are, however, as a rule ius dispositivum, thus the tour operators could exclude their application in contracts made with travellers, which would not guarantee adequate protection for said travellers.

Noticeably, directive no. 2015/2302 contains solutions which strengthen the position of tour operators with respect to general rules. An example of this is the provision of Article 11 (1) which allows a tour operator, with no risk of liability for applying prohibited contract clauses, for a reservation in a contract of a right to implement unilaterally nonsignificant changes. A similar regulation applies in the context of an increase in the price of package travel, providing the conditions of Article 10 (1\&3) were met and it does not exceed $8 \%$ of the original total price. Such changes do not give the traveller the right to terminate the contract without bearing the costs of such termination. Also, a reservation in a contract regarding the limitation of compensation to three times the whole price of package travel under Article 14(4) of the directive, if such provision did not exist, would be considered a prohibited contractual clause (in Poland Article 3853(2) of the Civil Code).

\section{Conclusions}

As results from the findings above, the European Union institutions applied various instruments and methods of protection of passengers using the services of carriers and tour operators. In the context of carriage services, the European Union legislator applied an instrument in the form of regulations, which do not contain, however, a comprehensive regulation of a contract of carriage for a given mode of transport, but only correct and supplement regulations contained in international conventions. Even though a regulation guarantees the most far-reaching 
harmonisation of the regulations within EU territory, but the method applied to regulate it gives rise to problems resulting from regulating a service of carriage with multiple legal acts issued by various legislators (at European Union, international and domestic levels). When it comes to the provisions regulating contracts for package travel, the European Union legislator used an instrument of a directive with a maximum level of harmonisation and generally refrained from granting travellers new rights with respect to general rules of performance of a contract and consequences of non-performance, which result from civil law. The European Union legislator wanted rather to introduce a certain - admissible from the axiological perspective - level of use of freedom of contracting by tour operators, allowing tour operators to impose on the weaker party to a contract, the traveller, unfavourable conditions. Moreover, it may seem that in some cases the point was to provide a tour operator itself with additional rights, which it would not have obtained even through contractual clauses without being accused of introducing prohibited clauses to a contract.

Irrespective of that, the choice of a different measure of regulation (a directive) than in the case of a contract of carriage of passengers, poses a risk of improper implementation. Unfortunately, the Polish act on package travel and linked travel arrangements is an example of this.

\section{References}

Ambrożuk, D. (2014). Kształtowanie się europejskiego prawa przewozu osób. In: T. Kocowski, K. Marak (eds.), Zmiany prawodawstwa gospodarczego w okresie transformacji ustrojowej w Polsce. Prace Naukowe Uniwersytetu Ekonomicznego we Wrocławiu, 362 , 11-24. DOI: 10.15611/pn.2014.362.01.

Ambrożuk, D. (2015). Dochodzenie roszczeń przysługujących podróżnym na podstawie rozporządzeń unijnych. Zeszyty Naukowe Uniwersytetu Szczecińskiego, 885, Problemy Transportu i Logistyki, 31, 155-169. DOI: 10.18276/ptl.2015.31-10.

Ambrożuk, D. (2017). O tzw. „przemienności drogi dochodzenia roszczeń” przysługujących podróżnym na podstawie rozporządzenia nr 261/2004. Internetowy Kwartalnik Antymonopolowy i Regulacyjny (iKAR), 3 (6), 48-60. Retrieved from: www.ikar.wz.uw.edu. pl. DOI: 10.7172/2299-5749.IKAR.3.6.4.

Ambrożuk, D., Wesołowski, K. (2001). Wybrane aspekty dostosowania prawa polskiego do prawa Unii Europejskiej w dziedzinie turystyki. In: B. Gnela, R. Szostak (eds.), Harmonizacja polskiego prawa gospodarczego z wymogami Unii Europejskiej (pp. 73106). Kraków: Zakamycze.

Ambrożuk, D., Wesołowski, K. (awaiting publication). Terminy na dochodzenie zryczałtowanych odszkodowań należnych pasażerom na podstawie rozporządzenie (WE) nr 261/2004.

Athens Convention relating to the Carriage of Passengers and their Luggage by Sea of 13.12.1974. - Dz.U. of 1987, No. 18, item 108 as amended by the Protocol to the Athens Convention of 19.11.1976 - Dz.U. of 1994, No. 99, item 479.

Convention concerning International Carriage by Rail (COTIF) of 9 May - Dz.U. of 1985, No. 34, item 158, as amended by the Vilnius Protocol of 3 June 1999 - Dz.U. of 2007, No. 100, item 674, Appendix A. Uniform Rules concerning the Contract of International Carriage of Passengers by Rail (CIV).

Convention for the Unification of Certain Rules for International Carriage by Air of 28.5.1999 - Dz.U. of 2007, No. 37 , item 235.

Convention for the Unification of Certain Rules Relating to International Carriage by Air of 12.10.1929 - Dz.U. of 1933, No. 8, item 49, amended by the Hague Protocol of 28.9.1955 - Dz.U. of 1963, No. 33, item 189.

Convention for the Unification of Certain Rules Relating to International Carriage by Air Performed by an Entity other than the Carrier under the Contract of 18.9.1961. Dz.U. of 1965, No. 25, item 167.

Court of Justice of the European Union: the judgement of 22 November 2012; C-139/11 Moré, (ECLI:EU:C:2012:741); the judgement of 22 October 2009; C-301/08 Bogiatzi (ECLI:EU:C:2009:649)

Directive (EU) 2015/2302 of the European Parliament and of the Council of 25 November 2015 on package travel and linked travel arrangements, amending Regulation (EC) No. 2006/2004 and Directive 2011/83/EU of the European Parliament and of the Council and repealing Council Directive 90/314/EEC (OJ UE 2015 L 326/1).

Gospodarek, J. (2001). Prawo turystyczne. Warszawa: Wydawnictwo Prawnicze. 
Gospodarek, J. (2014). Znaczenie dla rynku turystycznego projektowanej dyrektywy Parlamentu Europejskiego i Rady w sprawie imprez turystycznych i aranżowanych usług turystycznych. Zeszyty Naukowe Uniwersytetu Szczecińskiego, 807. Ekonomiczne Problemy Turystyki, 3 (27), 165-181.

Karsten, J. (2007). Passengers, consumers, and travellers: The rise of passenger rights in EC transport law and its repercussions for Community consumer law and policy. Journal of Consumer Policy, 30 (2), 117-136. https://doi.org/10.1007/s10603-007-9032-7.

Łętowska, E. (ed.). (2006). Prawo zobowiązań - część ogólna. System Prawa Prywatnego. Tom 5. Warszawa: C.H. BECK.

Marak, K. (2015). Harmonizacja maksymalna projektowanej dyrektywy turystycznej i możliwe odstępstwa od tak wyznaczonego poziomu harmonizacji. In: B. Gnela, K. Michałowska (eds.), Współczesne wyzwania prawa konsumenckiego (pp. 16-28). Warszawa: C.H. BECK.

Nesterowicz, M. (2012). Prawo turystyczne. Warszawa: Wolters Kluwer.

Polish Supreme Court: the resolution of the of 7 February 2014; III CZP 113/13 - Retrieved from: www.sn.pl/sistes/orzecznictwo/ orzeczenia2/iii czp 113-13.pdf; the resolution of 17 March 2017 r., III CZP 111/16 - Retrieved from: www.sn.pl/sistes/orzecznictwo/ orzeczenia3/iii czp 111-16.pdf.

Regulation (EC) No. 1107/2006 of the European Parliament and of the Council of 5 July 2006 concerning the rights of disabled persons and persons with reduced mobility when travelling by air (OJ UE 2006 L 204/1).

Regulation (EC) No. 1177/2010 of the European Parliament and of the Council of 24 November 2009 concerning the rights of passengers when travelling by sea and inland waterway and amending Regulation (EC) No 2006/2004 (OJ UE 2010 L 334/1).

Regulation (EC) No. 1371/2007 of the European Parliament and of the Council of 23 October 2007 on rail passengers' rights and obligations (OJ UE 2007 L 315/14).

Regulation (EC) No. 181/2011 of the European Parliament and of the Council of 16 February 2011 concerning the rights of passengers in bus and coach transport and amending Regulation (EC) No. 2006/2004 (OJ UE 2011 L 55/1).

Regulation (EC) No. $2027 / 97$ of 9.10 .1997 on air carrier liability in respect of the carriage of passengers and their baggage by air (OJ UE 1997 L 285/1) as amended by (EC) No. 889/2002 of the European Parliament and of the Council of 11.05.2002 (OJ UE 2002 L 140/2, Polish Special Edition 2004, chapter 7, vol. 6, p. 246).

Regulation (EC) No. 261/2004 of the European Parliament and of the Council of 11 February 2004 establishing common rules on compensation and assistance to passengers in the event of denied boarding and of cancellation or long delay of flights, and repealing Regulation (EEC) No. 295/91 (OJ UE 2004 L 46/1).

Regulation (EC) No. 392/2009 of the European Parliament and of the Council of 23 April 2009 on the liability of carriers of passengers by sea in the event of accidents (OJ UE 2009 L 131/24).

Treaty on the Functioning of the European Union (consolidated version - OJ EU 2012 C326/1).

Wesołowski, K. (2016). Multicentryczność regulacji prawnej usługi przewozu osób. Marketing i Zarządzanie, 1 (42), 201-215. DOI: 10.18276/miz.2016.42-14.

Cite this anticle aS: Ambrożuk, D. (2018). Varied methods of protection of travellers under European law. European Journal of Service Management, 3 (27/2), 9-15. DOI: 10.18276/ejsm.2018.27/2-01. 